\title{
Improvement of nutritional value and bioactivity of ricegrass as affected of priming induced by fish protein hydrolysate
}

\section{Rungtip Rattanapon, Sunisa Siripongvutikorn, Worapong Usawakesmanee, and Chakree Thongraung}

Department of Food Technology, Faculty of Agro-Industry, Prince of Songkla University, Hat Yai, Songkhla 90112, Thailand

Corresponding Author: Sunisa Siripongvutikorn, $\mathrm{PhD}$, Assistant Professor, Department of Food Technology, Faculty of Agro-Industry, Prince of Songkla University, Hat Yai, Songkhla, 90112, Thailand

Submission date: January 15, 2016; Acceptance date: April 25, 2016; Publication date: April 27, 2016

\begin{abstract}
Background: Wheatgrass (Triticum aestivum L.) is consumed worldwide and has been used for health benefits and as functional food or nutraceuticals. While ricegrass (Oryza sativa L.) is still not well documented, which is also in the grass family (Poaceae) as wheatgrass. Also, similar to wheatgrass, ricegrass is produced with aged around 8-10 d. Moreover, priming is a process for enhancing seed vigour properties and improving bioactive compounds. Utilization of fish protein hydrolysate (FPH) for liquid fertilizer is more interesting in order to increase the nutritional value and bioactive compounds as well as antioxidant activity of many plants.
\end{abstract}

Objective: To investigate the nutritional value and bioactivity of ricegrass affected by the priming process of fish protein hydrolysate.

Methods: The Chainat 1 rice seeds were soaked with FPH at 0, 5, 10, 15 and 20 ppm at a ratio of rice seed to FPH as 1:5 and grown for $7 \mathrm{~d}$, thereafter, the ricegrass seed vigour properties, nutritional value and bioactive compounds such as chlorophyll, carotenoids, total phenolic and phytic acid were determined. The ricegrass was extracted with water at a ratio 1:2 (ricegrass:water), then homogenized and centrifuged at 10000xg for $20 \mathrm{~min}$. Then the supernatant was brought to freeze dry. The freeze-dried powder was dissolved in distilled water and brought to measure total phenolic content by Folin-Ciocalteu method. Antioxidant activities were determined by 3 assays as ferric reducing antioxidant power (FRAP), 2,2-diphenyl-1-picryl hydrazyl radical (DPPH) and 2,2'-azino-bis-3-ethylbenzthiazoline-6-sulphonic acid radical (ABTS) methods.

Results: The results showed that FPH at $10 \mathrm{ppm}$ significantly improved $(p<0.05)$ seed vigour properties including germination percentage, germination rate, height and fresh weight and 
nutritional values such as ash, protein, fat and carbohydrate. In addition, bioactive compounds including chlorophyll $\mathrm{a}$ and $\mathrm{b}$, total chlorophyll and carotenoid content in ricegrass primed with 10 ppm FPH were higher than control. Phytic acid content in ricegrass primed with FPH at 5 and $10 \mathrm{ppm}$ but not 15 and $20 \mathrm{ppm}$ was lower than control. The ricegrass primed with FPH at $10 \mathrm{ppm}$ yielded highest total phenolic content. Though ABTS activity was not highest in rice primed with FPH at 10 ppm, DPPH and FRAP assays were highest.

Conclusion: The seed vigour property, nutritional value, bioactive compounds and antioxidant activity of ricegrass primed with FPH was significantly improved. The appropriate content of FPH for priming ricegrass was $10 \mathrm{ppm}$ because it demonstrated improvement in seed vigour, nutritional value and bioactive compounds including chlorophyll, carotenoid, total phenolic content and antioxidant activity determined as FRAP, DPPH and ABTS and reduced the antinutrient compounds as phytic acid.

Keywords: Ricegrass, Fish protein hydrolysate, Nutritional value, Bioactive compound, Antioxidant

\section{INTRODUCTION:}

Wheat, Triticum aestivum L. is widely consumed in mainly western countries in the form of grain or vegetable and juice. Making wheatgrass juice, the young grass stage aged about 7-8 d (1) is used. Recently, both freshly juiced and dried powder form of this grass is more interesting for human consumption because of their high chlorophyll content besides various amino acids, minerals, vitamins and enzymes (1). Chlorophyll has been proclaimed to help digestion, nourish blood flow and aid general detoxification of the body (1).

Rice, Oryza sativa L. is also classified in the grass family (Poaceae) as wheat, corn and barley and so on. Rice grain is one of the most important cereals in the world, apart from wheat and corn. Many nutrient components and bioactive compounds, known as antioxidants, including phenolic compounds are found in rice grain particularly brown or color rice types (2). Chainat 1 rice is a high productive type as it is non-sensitive to photoperiod and resistant to insects (3). In addition, with high amylose content, the cooked rice is hard and crumbles. Therefore Chainat 1 is famous for producing rice products such as noodle and starch. The phenolic content and antioxidant activity of Chainat rice was reported to be higher than glutinous rice (RD 6) and Red Jasmine rice (Hom Mali Deang) (4). Kaosa-ard and Songsermpong (5) reported that germinated Chainat 1 possessed higher gamma aminobutyric acid (GABA) content compared with ungerminated rice.

Seed priming is a common agronomic practice to enhance seed vigour properties and improve seedling development. Hydropriming, halopriming, osmopriming, hormonal priming and nutrient priming have been used for germination and seeding process (6). To improve seed vigour and increase phenolic compounds of many plants, using different priming chemicals has been reported. Moreover, corn, soy bean and tomato seedling were enhanced by using fish protein (6). 
Fish protein hydrolysates (FPH) produced from byproduct of fishery industry are now interesting. Actually, the utilization of FPH is common in a wide spectrum range for food and food ingredients as well as fertilizer (7). FPH is known to be rich in amino acids, which is essential for proline metabolism. Mackie (8) addressed that FPH contained high proline and proline precursors which have been demonstrated to have growth improvement in vitro tissue culture. All proline, proline precursor (glutamate) and proline analogue (hydroxyproline) can be exploited for plant tissue culture and propagation (9). Germination rate, plant height, fresh weight and total phenolic content of fava bean were significantly increased when primed with mackerel fish protein hydrolysate (10). However, seed vigour (weight and height), phenolic compounds, chlorophyll content and antioxidant activity of soybean and tomato were different and depended on FPH concentration during priming process (6). Using $5 \mathrm{ml} / \mathrm{l}$ of FPH had higher values in soybean compared with using $2.5 \mathrm{ml} / \mathrm{FPH}$ while seed vigour of tomatoes were highly increased when using $2.5 \mathrm{ml} / \mathrm{l} \mathrm{FPH} \mathrm{compared} \mathrm{to} 5 \mathrm{ml} / \mathrm{l}$.

Only wheatgrass juice is very popular and has been used for functional, nutraceutical food to serve health benefit, in fact rice is in the grass family; Poaceae as wheat. In addition, malting of wheatgrass and ricegrass is also produced with aged around 8-10 d (4) but using of ricegrass as functional food or juice or food ingredient is not well established. From the literature review, the fish protein hydrolysate priming has been reported for improving nutritional value and bioactivity in some plants such as corn, soybean and tomato (6). Therefore, this study aimed to use FPH for improving germinated rice. Additionally, the chemical compositions, bioactive compounds and antioxidant activity of ricegrass were also monitored.

\section{MATERIALS AND METHODS:}

Materials: The rough rice of Chainat 1 variety with moisture content less than $14 \%$ was obtained from Phattlung rice research center located in Phattalung, Thailand. The rice was harvested in June, 2014. The rice seed was used as the primary sample within 6 mo. The rice seeds were soaked with fish protein hydrolysates solution (at ratio of rice seed to fish protein hydrolysate solution as 1:5) at different concentrations $(0,5,10,15$ and $20 \mathrm{mg} / \mathrm{l})$ for $24 \mathrm{~h}$ at room temperature $\left(28 \pm 2{ }^{\circ} \mathrm{C}\right)$. The untreated primed seeds were washed with tap water then, spread on surface of the soil filled in plantation bed. Five-hundred millilitres of water was sprayed on the plantation bed size $35.5 \times 55 \times 4.5 \mathrm{~cm}$ every day for $7 \mathrm{~d}$.

\section{METHODS}

\section{Seed vigour properties}

The seed vigour properties included germination rate, plant height and fresh weight. The germination rate was calculated as equation 1 .

$$
\text { Germination rate }=\frac{\text { Total number of seedling emergence }}{\text { Total number of rice seed }}
$$

The plant height determined as shoot height above the soil was directly measured. The fresh weight of seedling was measured after plant was cut from above the soil (7). 


\section{Nutritional value}

Nutritional values of ricegrass including moisture, protein, fat, fiber, ash and carbohydrate contents were analyzed following the AOAC (2000).

\section{Bioactive compounds}

The shoots above the ground $1 \mathrm{~cm}$ were cut, washed with tap water, drained for $2 \mathrm{~min}$ and kept at $4{ }^{\circ} \mathrm{C}$ until analysis.

\section{Determination of chlorophyll and carotenoid content}

Chlorophyll a, b content and carotenoid content of ricegrass shoots were analyzed following the AOAC (1990).

\section{Determination of phytic acid content}

Phytic acid content was determined by the method of Haug and Lantzsch (11). Briefly, the sample (0.8-1.0 g) was extracted with $25 \mathrm{ml}$ of $0.2 \mathrm{~N} \mathrm{HCl}$ in flask and shaken for $1 \mathrm{~h}$ on shaker at $30^{\circ} \mathrm{C}$, thereafter mixture was added with $1 \mathrm{ml}$ acidic ammonium iron-III sulphate $\left(\mathrm{FeNH}_{4}\left(\mathrm{SO}_{4}\right)_{2}\right)$ solution and heated at $105{ }^{\circ} \mathrm{C}$ for $30 \mathrm{~min}$. After cooling down, the solution was centrifuged at $1600 \mathrm{xg}$ for $30 \mathrm{~min}$, then the supernatant $(1 \mathrm{ml})$ was transferred to test tube and $1.5 \mathrm{ml}$ of 2,2bipyridine solutions was added. The absorbance was measured at $519 \mathrm{~nm}$. A decrease in absorbance of iron content, in the supernatant was measured and taken to calculate for phytic acid contents.

\section{Total phenolic and antioxidant activity}

Preparation of ricegrass extract

The ricegrass shoots from each treatment were homogenized with water at ratio of ricegrass to water as 1:2 for $5 \mathrm{~min}$, centrifuged at $10000 \mathrm{~g}$ for $20 \mathrm{~min}$, and the supernatant was freeze dried. The powder was stored at $-20{ }^{\circ} \mathrm{C}$ until further analysis.

\section{Determination of total phenolic content}

The powder of ricegrass extract $(0.1 \mathrm{~g})$ was dissolved in distilled water $(10 \mathrm{ml})$ to obtain stock solution for measurement total phenolic content (12). The total phenolic content of the ricegrass was measured using a modified Folin-Ciocalteu method (13). Briefly, the ricegrass extract $0.5 \mathrm{ml}$ was put into volumetric flask, then added with $10 \%$ (v/v) Folin-Cioculteu reagent $5 \mathrm{ml}$ and allowed to stand at room temperature for $5 \mathrm{~min}$. Thereafter $4 \mathrm{ml}$ of $1 \mathrm{M} \mathrm{Na}_{2} \mathrm{CO}_{3}$ was added and adjusted final volume to $10 \mathrm{ml}$, kept in dark for $90 \mathrm{~min}$. The absorbance was measured at 750 $\mathrm{nm}$. The measured values were compared with a standard curve of various gallic acid and expressed as milligram of gallic acid equivalents/g ricegrass.

\section{Determination of antioxidant activities}

Radical scavenging assay by using DPPH; The working solution of ricegrass extract was made from stock solution mentioned in 2.4.2 then ricegrass extract $(1.5 \mathrm{ml})$ from the right concentration was added with $1.5 \mathrm{ml}$ of $0.15 \mathrm{mM}$ 2,2-diphenyl-1-picryl hydrazyl (DPPH) in $95 \%$ ethanol. The mixture was mixed and allowed to stand for $30 \mathrm{~min}$ at room temperature in the 
dark. The absorbance of the resulting solution was measured at $517 \mathrm{~nm}$ using spectrophotometer. The blank prepared in the same manner, except that distilled water was used instead of the sample. A standard curve was prepared using Trolox in the range of $10-60 \mu \mathrm{M}$. The activity was expressed as $\mu \mathrm{mol}$ Trolox equivalents (TE)/g ricegrass (14).

ABTS radical scavenging activity; The stock solutions included $7.4 \mathrm{mM}$ 2,2'-azino-bis-3ethylbenzthiazoline-6-sulphonicacid (ABTS) solution and $2.6 \mathrm{mM}$ potassium persulphate solution were prepared. The working solution was prepared by mixing the two stock solutions in equal quantities and allowed them to react for $12 \mathrm{~h}$ at room temperature in the dark. The extract $(150 \mu \mathrm{l})$ was mixed with $2850 \mu \mathrm{l}$ of ABTS solution and left at room temperature for $2 \mathrm{~h}$ in the dark. The absorbance was measured at $734 \mathrm{~nm}$ using the spectrophotometer. A standard curve of Trolox ranging from 50 to $600 \mu \mathrm{M}$ was prepared. The activity was expressed as $\mu \mathrm{mol}$ Trolox equivalents $(\mathrm{TE}) / \mathrm{g}$ rice grass (14).

Ferric reducing antioxidant power; Stock solutions included $300 \mathrm{mM}$ acetate buffer (pH 3.6), 10 mM TPTZ (2,4,6-tripyridyl-s-triazine) solution in $40 \mathrm{mM} \mathrm{HCl}$, and $20 \mathrm{mM} \mathrm{FeCl}_{3} .6 \mathrm{H}_{2} \mathrm{O}$ solution were prepared. A working solution was prepared freshly by mixing $25 \mathrm{ml}$ of acetate buffer, 2.5 $\mathrm{ml}$ of TPTZ solution and $2.5 \mathrm{ml}$ of $\mathrm{FeCl}_{3} \cdot 6 \mathrm{H}_{2} \mathrm{O}$ solution. The mixed solution was incubated at 37 ${ }^{\circ} \mathrm{C}$ for $30 \mathrm{~min}$ and been referred as FRAP solution. The rice grass extract (150 $\left.\mu 1\right)$ was mixed with $2850 \mu \mathrm{l}$ of FRAP solution and kept for $30 \mathrm{~min}$ in the dark. The ferrous tripyridyltriazine complex was measured by reading the absorbance at $593 \mathrm{~nm}$. The standard curve was prepared using Trolox ranging from50 to $600 \mu \mathrm{M}$. The activity was expressed as $\mu$ mol Trolox equivalents $(\mathrm{TE}) / \mathrm{g}$ rice grass $(14)$.

Statistical: The data was subjected to Analysis of Variance (ANOVA) and the differences between means were evaluated by Duncan's Multiple Range Test.

\section{RESULTS:}

Seed vigour properties: The result found that using FPH as priming solution improved seed vigour properties of ricegrass as showed in Figure 1. In addition, ricegrass primed with $10 \mathrm{ppm}$ FPH possessed the highest seed vigour properties.

Nutritional values: Using FPH priming influenced nutritional values of ricegrass including ash, protein, fat and carbohydrate content except moisture and fiber content (Table 1). The ash content of ricegrass primed with FPH at $10 \mathrm{ppm}$ was higher than other FSH treatments but was not significantly different when compared with control rice $(p>0.05)$. The highest protein content of ricegrass was found in ricegrass primed with FPH at $10 \mathrm{ppm}(p<0.05)$. It was noticed that the content of protein was decreased in ricegrass when primed with FPH at high concentration (15 and $20 \mathrm{ppm}$ ). Moreover, fat content of ricegrass primed with FPH were higher than control rice sample. However, fat content in ricegrass primed with FSH at $5 \mathrm{ppm}$ and $20 \mathrm{ppm}$ were lower compared with 10 and $15 \mathrm{ppm}$ treatments. Moreover, carbohydrate content of ricegrass was highest at 10 and 15 ppm of FPH. 


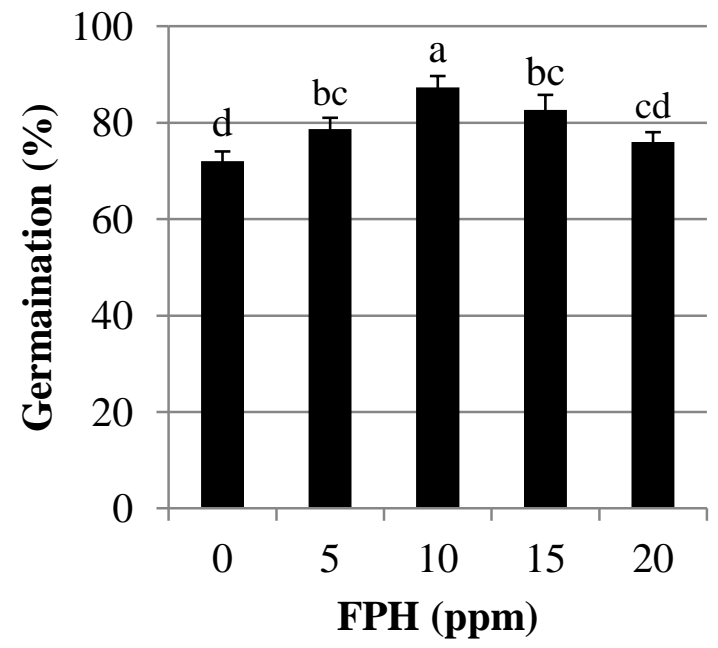

(A)

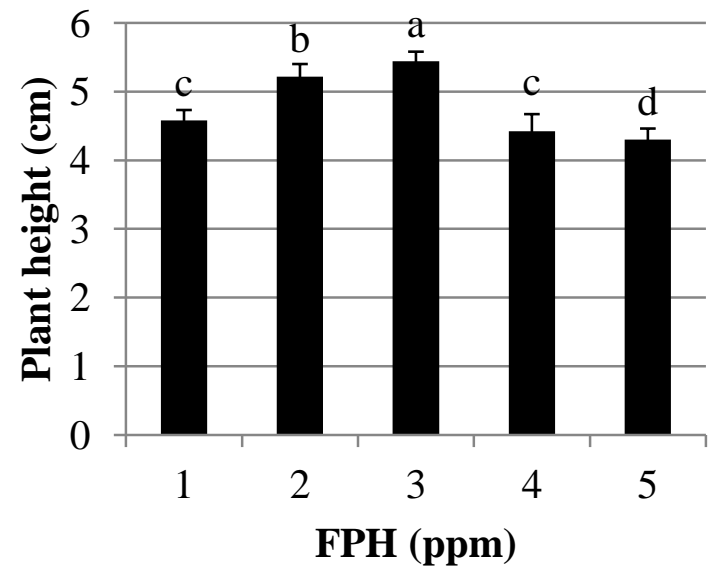

(C)

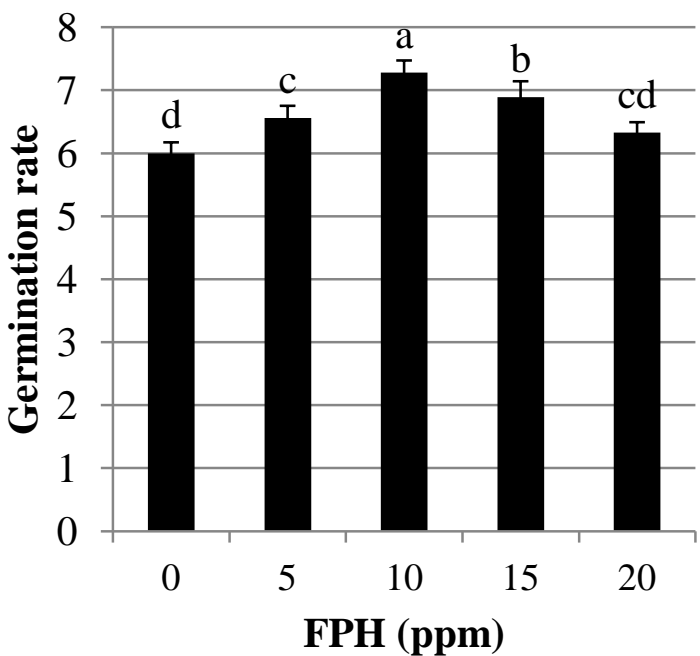

(B)

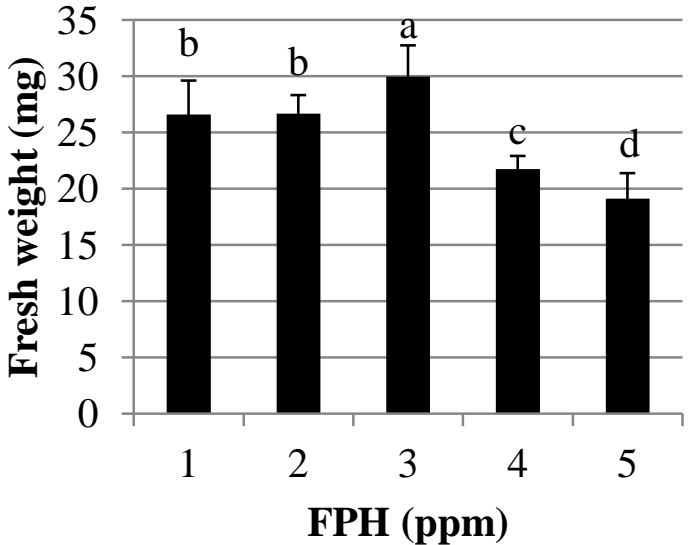

(D)

Figure 1. Seed vigour properties (A) germination (\%), (B) germination rate, (C) plant height and (D) fresh weight of ricegrass as affected of fish protein hydrolysate priming. Each value was expressed as the mean \pm standard deviation $(\mathrm{n}=3)$. Different little letters indicate significant differences $(\mathrm{p}<0.05)$

Table 1. Nutritional values of ricegrass as affected of protein hydrolysate priming

\begin{tabular}{cllllll}
\hline $\begin{array}{c}\text { FSH } \\
(\mathrm{ppm})\end{array}$ & $\begin{array}{l}\text { Moisture } \\
(\%)\end{array}$ & $\begin{array}{l}\text { Ash } \\
(\%)\end{array}$ & $\begin{array}{l}\text { Protein } \\
(\%)\end{array}$ & $\begin{array}{l}\text { Fat } \\
(\%)\end{array}$ & $\begin{array}{l}\text { Carbohydrate } \\
(\%)\end{array}$ & $\begin{array}{l}\text { Fiber } \\
(\%)\end{array}$ \\
\hline 0 & $83.84 \pm 0.23^{\mathrm{ns}}$ & $2.17 \pm 0.03^{\mathrm{a}}$ & $3.32 \pm 0.05^{\mathrm{ab}}$ & $1.07 \pm 0.08^{\mathrm{d}}$ & $9.60 \pm 0.12^{\mathrm{a}}$ & $2.73 \pm 0.11^{\mathrm{ns}}$ \\
5 & $85.87 \pm 0.12^{\mathrm{ns}}$ & $2.03 \pm 0.07^{\mathrm{b}}$ & $3.24 \pm 0.09^{\mathrm{ab}}$ & $1.20 \pm 0.06^{\mathrm{c}}$ & $7.66 \pm 0.28^{\mathrm{b}}$ & $2.66 \pm 0.17^{\mathrm{ns}}$ \\
10 & $83.67 \pm 0.45^{\mathrm{ns}}$ & $2.13 \pm 0.06^{\mathrm{a}}$ & $3.33 \pm 0.09^{\mathrm{a}}$ & $1.31 \pm 0.03^{\mathrm{ab}}$ & $9.56 \pm 0.41^{\mathrm{a}}$ & $2.69 \pm 0.12^{\mathrm{ns}}$ \\
15 & $84.14 \pm 0.02^{\mathrm{ns}}$ & $2.09 \pm 0.01^{\mathrm{ab}}$ & $3.06 \pm 0.08^{\mathrm{b}}$ & $1.36 \pm 0.04^{\mathrm{a}}$ & $9.35 \pm 0.07^{\mathrm{a}}$ & $2.67 \pm 0.06^{\mathrm{ns}}$ \\
20 & $84.07 \pm 0.79^{\mathrm{ns}}$ & $2.09 \pm 0.05^{\mathrm{ab}}$ & $3.11 \pm 0.19^{\mathrm{b}}$ & $1.26 \pm 0.02^{\mathrm{bc}}$ & $8.08 \pm 1.68^{\mathrm{b}}$ & $2.79 \pm 0.12^{\text {ns }}$ \\
\hline
\end{tabular}

Each value was expressed as the mean \pm standard deviation $(n=3)$. Different little letters in the same column indicate significant differences $(\mathrm{p}<0.05)$ 
Chlorophyll and carotenoid content: The FPH treatment significantly stimulated chlorophyll and carotenoid content of ricegrass $(p<0.05)$ as showed in Table 2, which was higher than control. Chlorophyll a and total chlorophyll content in ricegrass primed with FPH at 15 and 20 ppm was similar and seemed to be higher compared with other treatments, while chlorophyll b content was highest in ricegrass primed with FPH at $5 \mathrm{ppm}$. Moreover, carotenoid content was increased when FPH increased.

Table 2. Chlorophyll and carotenoid content of ricegrass as affected of protein hydrolysate priming

\begin{tabular}{ccccc}
\hline $\begin{array}{c}\text { FPH } \\
(\mathrm{ppm})\end{array}$ & $\begin{array}{c}\text { Chlorophyll a } \\
(\mathrm{mg} / \mathrm{g})\end{array}$ & $\begin{array}{c}\text { Chlorophyll b } \\
(\mathrm{mg} / \mathrm{g})\end{array}$ & $\begin{array}{c}\text { Total chlorophyll } \\
(\mathrm{mg} / \mathrm{g})\end{array}$ & $\begin{array}{c}\text { Carotenoid } \\
(\mathrm{mg} / \mathrm{g})\end{array}$ \\
\hline 0 & $0.35 \pm 0.02^{\mathrm{c}}$ & $0.22 \pm 0.01^{\mathrm{c}}$ & $0.74 \pm 0.04^{\mathrm{c}}$ & $0.21 \pm 0.00^{\mathrm{c}}$ \\
5 & $0.48 \pm 0.04^{\mathrm{ab}}$ & $0.28 \pm 0.01^{\mathrm{a}}$ & $1.02 \pm 0.06^{\mathrm{a}}$ & $0.26 \pm 0.02^{\mathrm{b}}$ \\
10 & $0.43 \pm 0.05^{\mathrm{b}}$ & $0.23 \pm 0.03^{\mathrm{bc}}$ & $0.90 \pm 0.10^{\mathrm{b}}$ & $0.24 \pm 0.03^{\mathrm{b}}$ \\
15 & $0.52 \pm 0.01^{\mathrm{a}}$ & $0.26 \pm 0.02^{\mathrm{ab}}$ & $1.09 \pm 0.03^{\mathrm{a}}$ & $0.32 \pm 0.01^{\mathrm{a}}$ \\
20 & $0.50 \pm 0.01^{\mathrm{a}}$ & $0.22 \pm 0.01^{\mathrm{c}}$ & $1.03 \pm 0.00^{\mathrm{a}}$ & $0.30 \pm 0.01^{\mathrm{a}}$
\end{tabular}

Each value was expressed as the mean \pm standard deviation $(n=3)$. Different little letters in the same column indicate significant differences $(\mathrm{p}<0.05)$

Phytic acid content: The rice seed contained phytic acid content about $11.19 \%$, thereafter this content was diminished during sprouting. Comparing of priming effect, it was found that concentration of FPH had affected phytic acid content of ricegrass as showed in Table 3. The phytic acid content of ricegrass primed with FPH at 5 and $10 \mathrm{ppm}$ significantly decreased $(p<0.05)$ thereafter, it increased. Moreover, the phytic acid content was highest in ricegrass primed with 20 ppm among the primed seed samples.

Table 3. Phytic acid content of ricegrass as affect as protein hydrolysate priming

\begin{tabular}{cc}
\hline FPH $(\mathrm{ppm})$ & Phytic acid (\%) \\
\hline Rice seed & $11.19 \pm 0.05^{\mathrm{a}}$ \\
0 & $1.61 \pm 0.05^{\mathrm{c}}$ \\
5 & $0.95 \pm 0.05^{\mathrm{e}}$ \\
10 & $1.32 \pm 0.03^{\mathrm{d}}$ \\
15 & $1.56 \pm 0.05^{\mathrm{c}}$ \\
20 & $1.80 \pm 0.05^{\mathrm{b}}$ \\
\hline
\end{tabular}

Each value was expressed as the mean \pm standard deviation $(n=3)$. Different little letters in the same column indicate significant differences $(\mathrm{p}<0.05)$. 
Total phenolic compounds: Priming the rice seed with FPH had a great effect on total phenolic content as showed in Figure 2. The FPH priming significantly increased total phenolic content in ricegrass compared with control sample $(p<0.05)$. The total phenolic content of ricegrass started to increase and peaked highest at $10 \mathrm{ppm}$ of FPH, then decreased when concentration of FPH was higher than $10 \mathrm{ppm}$ (15 and $20 \mathrm{ppm})$.

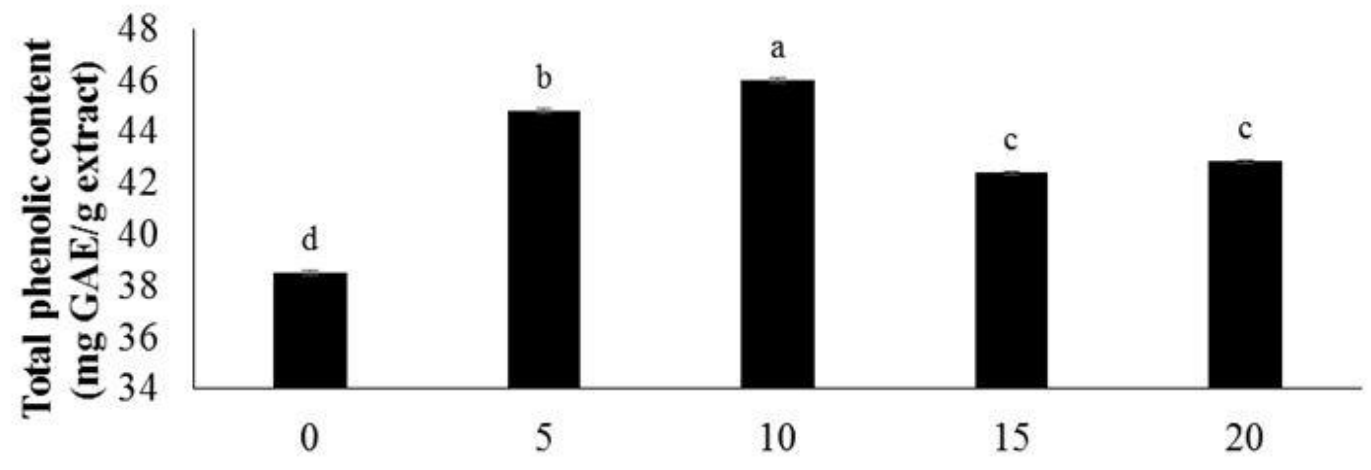

FPH (ppm)

Figure 2. Total phenolic content of ricegrass as affected of fish protein hydrolysate priming Each value was expressed as the mean \pm standard deviation $(n=3)$. Different little letters indicate significant differences $(\mathrm{p}<0.05$

Antioxidant activity: The antioxidant activity of ricegrass primed with FPH showed in Table 4. It was found that FPH priming significant improved antioxidant activity of ricegrass when determined by DPPH, ABTS and FRAP assay $(p<0.05)$. The results showed that DPPH radicals scavenging activity was highest in ricegrass primed with FPH at $10 \mathrm{ppm}$. However, the ABTS radicals scavenging activity was highest in ricegrass primed with FPH at $5 \mathrm{ppm}$. Moreover, the FRAP assay of ricegrass primed with FPH at 10 and 15 ppm was higher than other treatments.

Table 4. Antioxidant activity (DPPH, ABTS and FRAP) of ricegrass as affected of fish protein hydrolysate priming

\begin{tabular}{cccc}
\hline & \multicolumn{3}{c}{$\begin{array}{c}\text { Antioxidant } \\
\text { activity }\end{array}$} \\
\cline { 2 - 4 } FPH $(\mathrm{ppm})$ & $\begin{array}{c}\text { ABTS } \\
(\mathrm{mmpH}\end{array}$ & $\begin{array}{c}\text { FRAP } \\
(\mathrm{mmol} \mathrm{TE} / \mathrm{g})\end{array}$ \\
\hline 0 & $89.32 \pm 0.57^{\mathrm{e}}$ & $129.63 \pm 1.21^{\mathrm{e}}$ & $335.84 \pm 6.34^{\mathrm{d}}$ \\
5 & $124.79 \pm 0.57^{\mathrm{c}}$ & $315.78 \pm 1.21^{\mathrm{a}}$ & $452.91 \pm 9.70^{\mathrm{b}}$ \\
10 & $164.09 \pm 0.98^{\mathrm{a}}$ & $241.62 \pm 0.45^{\mathrm{b}}$ & $571.95 \pm 9.57^{\mathrm{a}}$ \\
15 & $139.15 \pm 1.73^{\mathrm{b}}$ & $239.31 \pm 1.22^{\mathrm{c}}$ & $565.21 \pm 9.74^{\mathrm{a}}$ \\
20 & $107.51 \pm 1.15^{\mathrm{d}}$ & $210.85 \pm 1.21^{\mathrm{d}}$ & $431.75 \pm 6.35^{\mathrm{c}}$ \\
\hline
\end{tabular}

Each value was expressed as the mean \pm standard deviation $(n=3)$. Different little letters in the same column indicate significant differences $(\mathrm{p}<0.05)$. 


\section{DISCUSSION:}

Seed priming is a common agronomic practice to enhance seed vigour properties and improve seedling development. From this experiment, it was found that fish protein hydrolysate (FPH) priming could improve seed vigour property of ricegrass at appropriate concentration. Thomson et al. (15) addressed that humus and/or added fertilizer in the soil is a major source of nitrogen element for synthesis of essential amino acids for supporting seed vigour. Milazzo et al. (16) explained that FPH was rich in proline, which help stimulate plant growth and development. However, seed vigour was significantly inhibited when a FPH solution higher than $10 \mathrm{ppm}$ was applied. The result showed that seed vigour responded to FPH as bell curve, which may be explained by an adverse osmotic effect at high concentration of FPH (17). It pointed out that the FPH priming improved rice vigour when appropriate amount was used, thereafter it also had a negative effect. Horii et al. (6) stated that germination percentage, weight and height of tomato and soy bean sprout were highest at $5 \mathrm{ml} / \mathrm{l} \mathrm{FPH}$ compared with $2.5 \mathrm{ml} / \mathrm{l} \mathrm{FPH}$ and control. In contrast, plant height of corn sprout was highest at $2.5 \mathrm{ml} / \mathrm{l} \mathrm{FPH}$. However, priming with $2 \mathrm{ml} / \mathrm{l}$ FPH increased germination rate of fava beans seeds (18). Therefore, it can be concluded that increasing of seeds germinate rate depended on not only FPH concentration but also plant species.

Moreover, FPH priming affected nutritional values of ricegrass. This may be due to fish protein hydrolysate as a source of amino acid and nitrogen element, which plays a great role in synthesis of nutrients in plants. Mohammad (19) addressed that $\mathrm{N}$ fertilizer significantly affected the nutritional values of grasses. Moreover, nitrogen is an important element for protein synthesis in plants. Almodares et al. (20) explained that an increase of protein contents with increased fertilizer levels due to $\mathrm{N}$ fertilizer could enhance amino acid formation in plants. In contrast, Khumkha (21) explained that excessive amounts of nitrogen could be toxic in plant cells, therefore the protein content may be reduced. Mohammad et al. (22) reported that the crude protein content of napier grass treated with $\mathrm{N}$ fertilizer was higher than control, and increasing amount of protein was found with increased $\mathrm{N}$ fertilizer. Hasan et al. (23) supported that the protein content of cowpea forage was influenced by the increasing level of nitrogen fertilizer. Moreover, some amino acids contained in FPH are precursor compounds for lipid synthesis in plants through acetyl-CoA pathway for fatty acid producing (24). Mohammad et al. (22) reported that ash content was not influenced by the increasing levels of $\mathrm{N}$ fertilizer. In contrast, ash content was slightly decreased at high levels of $\mathrm{N}$ fertilizer (19). Therefore, it pointed out that the improvement of nutritional value of ricegrass depended on appropriate concentration of FPH.

Chlorophyll and carotenoids are photosynthetic pigments in plants. The results found that these pigments responded to FSH priming. Reinbothe and Reinbothe (25) reported that FPH is rich in glutamic acid, which is the initial amino acid substrate of chlorophyll biosynthesis in plants. Moreover, Daughtry et al. (26) mentioned that nitrogen compounds obtained in FPH is a structural element of chlorophyll, which affects chloroplasts formation and chlorophyll accumulation in plants. Besides that, cytokinins and cytokinin-like compounds could be stimulated in chlorophyll synthesis. Therefore, FPH may contain a cytokinin-like compound from protein resources. Imai et al. (27) suggested that cytokinin may stimulate chlorophyll 
biosynthesis by affecting the amount of mRNA related to chlorophyll a/b binding protein and small subunit of ribulose-1,5-bisphosphate carboxylase oxygenase. Horii et al. (6) stated that chlorophyll content of soybean primed with FPH was increased, due to combination of glutamic acid substrate in FPH and endogenous cytokinin in soybean, which stimulated chlorophyll biosynthesis by proline linked PPP activity. Kansal et al. (28) reported that nitrogen fertilizer increased the chlorophyll content and associated light absorbing pigment (including carotenoid) in vegetables. However, an increase of chlorophyll and carotenoid in this work was presented as a sigmoid curve. It meant that certain amounts of FPH increased chlorophyll content then once FPH content reached higher levels this would have an adverse effect. Chenard et al. (29) reported that the chlorophyll and carotenoid contents of parsley responded to nitrogen fertilization, the more treated $\mathrm{N}$ with the more carotenoids content. In addition, Khumkha (30) reported that the carotenoid content of rice seedling treated with nitrogen fertilizer (NF) at 400 ppm was higher than $200 \mathrm{ppm}$. In contrast, carotenoids content of sorghum seedling treated with 400 ppm of NF was lowest compared with 200 ppm and control. Moreover, carotenoids of corn seedling and wheatgrass treated with 400 ppm of NF were lower than 200 ppm (30). Generally, it was found that there was a good relationship between total chlorophyll and carotenoid content due to associated chlorophyll and carotenoid biosynthetic pathways. The signalling functions of intermediate compounds of chlorophyll biosynthesis regulate the transcription of light-harvesting chlorophyll-binding proteins and these proteins are also responsible for carotene and xanthophyll binding (31). Gibson (32) suggested that nitrogen is the important element for photosynthetic pigment synthesis while the carotenoids accumulate in the photosynthetic thylakoid membranes of green leaves, where they are bound to specific chlorophyll/carotenoid-binding protein complexes of the two photosystems (33). Moreover, carotenoids act as accessory photosynthetic pigments, with the main functions of light-harvesting and excess energy dissipation. The carotenoids are capable of quenching singlet oxygen and triplet excited chlorophyll, so when light intensity exceeds the photosynthetic capacity the carotenoids are more produced to protect cell death (34).

Phytic acid is an anti-nutritional substance in cereals, it can affect mineral absorption in the body. The reduction of phytic acid in ricegrass compared with rice seed may be due to an increase in phytase activity to hydrolyze phytic acid to myoinositol and phosphoric acid during seedling (35). It pointed out that sprouting process could significantly reduce phytic acid content; howver, using higher FPH concentration could also increase this compound. An increase of phytic acid content due to an increase of FPH may be due to FPH, which is a source of amino acid and nitrogen containing compounds such as glutamine, purine and pyrimidine nucleotides, stimulated by phytase activity. Moreover, the biological function of phytase is to liberate inorganic P to provide sufficient amounts for germinating seeds and growing plants. In contrast, excessive $\mathrm{P}$ availability in plants will inhibit the phytase activity (36). Kaya et al. (37) reported that the phytase activity in chickpea treated with $\mathrm{N}$ fertilizer was higher than control.

It is known that phenolic compounds are produced as secondary metabolic substances during plant growth. The result indicated that FPH could stimulate plant phenolic compound contents during priming process. It may be due to amino acid derived from FPH stimulated proline -linked PPP (38). This result agreed with the findings of Horii et al. (6) who explained 
that FSH enhanced phenolic compounds in corn, soybean and tomato via proline-linked pentose phosphate pathway (PPP) and shikimate pathway. Shetty (38) reported that proline and glutamic acid content in FPH played a key role for supporting proline metabolism and promoting PPP supported phenolic synthesis. Moreover, the result of this study indicated that total phenolic content in ricegrass depended on the concentration of FPH, as bell shape or Gaussian distribution, this may due to nitrogen levels or the concentration of FPH that affect the production of secondary metabolites in plants (39). Based on the carbon/nutrient balance (CNB) theory, under limited nutrient conditions or low nitrogen fertilization levels, the production of carbon-based secondary compounds as well as phenolic compounds in plants was increased. In contrast, the production of phenolic compounds decreased in presence of increased nitrogen fertilization levels (40). Stefanelli et al. (41) addressed that excess nitrogen availability has inhibited biosynthesis of phenolic compounds and subsequently antioxidant activity in plants. For example, the phenolic content of dark opal basil was lowest when applied nitrogen content was highest $(5.0 \mathrm{mM})$ compared with $1,0.5$ and $0.1 \mathrm{mM}$ of nitrogen content (42).

The antioxidant activity of ricegrass depended on the concentration of FPH priming. It was hypothesized that primed ricegrass with FPH at the right concentration yielded the highest total phenolic content associated with antioxidant activity. The antioxidant activity measured by DPPH, ABTS and FRAP assays are usually classified as radical quenching via hydrogen atom transfer and/or reduction via electron transfer (43). A comparison of antioxidant activity between these assays showed that FRAP value was highest for all treatments followed by ABTS and DPPH, respectively. This result could be explained by the fact that the ricegrass was extracted with high polarity solvent as water, thus the hydrophilic compounds in ricegrass may be more dissolved. In addition, FRAP assay was analyzed based on the electron transfer property of the compound in acidic conditions (44), which indicated that the bioactive compounds had high ferric reducing capacities or donated electrons to reduce $\mathrm{Fe}^{3+}$ to $\mathrm{Fe}^{2+}$. Whilst, the ABTS assay can be used to evaluate the antioxidant activity of both hydrophilic and lipophilic active compounds (45), the DPPH assay was used to determine only hydrophilic compounds. Moreover, it was assumed that since the phenolic compound types and content and/or other compounds such as carbohydrate, protein and fat content had affected extraction ability then antioxidant property would also be affected. In addition, structural and polarity as well as property of solvent, antioxidants present in the ricegrass and radical of each assay were also important. For example, though DPPH and ABTS assay determined the $\mathrm{H}^{+}$donor of antioxidant, there were some differences such as the structure of DPPH radical which was easily to attached with the $\mathrm{H}^{+}$derived from the antioxidant when its polarity was less because of less eclipsed conformation. However, when the antioxidant was high polarity, ABTS value was higher compared with DPPH value because of its polarity not structure problem. Kapkum et al. (21) suggested that the ricegrass (Hom Dang Sukhothai 1) had higher ferric reducing ability (FRAP value) than that ABTS value. Thongboon et al. (46) reported that the antioxidant activity of Hom Dang Sukhothai 1 ricegrass was highest compared with wheatgrass and barley grass. Moreover, using FRAP activity obtained higher value compared to value obtained from using ABTS radicals scavenging activity. 


\section{CONCLUSIONS:}

Seed vigour properties, nutritional values, bioactive compounds and antioxidant activity in ricegrass significantly increased when FPH at $10 \mathrm{ppm}$ was primed in the seeds. Phytic acid content significantly decreased during rice germination. In general, FRAP activity was higher than other antioxidant assays including ABTS and DPPH. To sum up, FPH priming could be used for improving seedling, secondary metabolite compounds and antioxidant activity. Therefore, ricegrass primed with FSH could be potentially applied to produce functional foods in the future.

Abbreviations: Fish protein hydrolysate (FPH), Proline-linked pentose phosphate pathway (PPP), Nitrogen fertilizer (NF), Ferric reducing antioxidant power (FRAP)

Competing interests: The authors declare that they have no competing interests

\section{Author's contributions:}

Rungtip Rattanapon, BSc, MSc is a Food Technologist and performed all of the laboratory work for the study and provided statistical analysis and assisted in writing the manuscript.

Sunisa Siripongvutikorn, PhD is an Assistant Professor of Food Technology. She is principal investigator for this study providing oversight and contributing fundamental conceptualization for the research, writing the grant proposal and manuscript.

Worapong Usawakesmanee, $\mathrm{PhD}$ is a Food Technology. He coordinated the initiatives to accelerate the development and subsequent production of the intervention meal. He also contributed in the study design and assisted in writing the manuscript.

Chakree Thongraung, PhD is an Assistant Professor of Food Technology. He supported fish protein hydrolysate for this experiment.

Acknowledgements: The authors would like to thanks the Graduate School and University Research Funding AGR580080S, Prince of Songkla University, Thailand, for the financial support.

\section{REFERENCES:}

1. Padalia, S., Drabu, S., Raheja, I., Gupta, A. and Dhamija, M. Multitude potential of wheatgrass juice (green blood): An overview. Chron Young Sci 2010; 1(2):8-23.

2. Frei, M., and Becker, K. Agro-biodiversity in subsistence-oriented farming systems in a Philippine upland region: nutrition considerations. Biodiver Conser 2004; 13:15911610.

3. Vetayasuporn, S. Effects of organic-chemical fertilizer on the growth and yield of rice (Chai Nat 1). Res J Biol Sci 2012; 7(7):265-269.

4. Vichapong, J., Sookserm, M., Srijesdaruk, V., Swatsitang, P. and Srijaranai, S. High performance liquid chromatographic analysis of phenolic compounds and their antioxidant activities in rice varieties. Food Sci Technol 2010; 43:1325-1330. 
5. Kaosa-ard, T. and Songsermpong, S. Influence of germination time on the GABA content and physical properties of germinated brown rice. Asian J Food Agro 2012; 5(4):270-283.

6. Horii, A., McCue, P. and Shetty, K. Seed vigour studies in corn, soybean and tomato in response to fish protein hydrolysates and consequences on phenolic-linked responses. Biores Technol 2007; 98:2170-2177.

7. Randhir, R. and Shetty, K. Developmental stimulation of total phenolics and related antioxidant activity in light and dark-germinated corn by natural elicitors. Proc Biochem 2005; 40:1721-1732.

8. Mackie, I.M. Fish protein hydrolysates. Proc Biochem 1982; 17:9-26.

9. Andarwulan, N. and Shetty, K. Influence of fish protein hydrolysates in combination with acetyl salicylic acid on hyperhydricity reduction and phenolic synthesis in oregano (Origanum vulgare) tissue cultures. J Food Biochem 1999; 23:619-635.

10. Randhir, R. and Shetty, K. Light-mediated fava bean (Vicia faba) response to phytochemical and protein elicitors and consequences on nutraceutical enhancement and seed vigor. Proc Biochem 2003; 38:945-952.

11. Haug, W. and Lantzsch, H.J. Sensitive method for the rapid determination of phytate in cereals and cereal products. J Food Sci 1983; 34:1423-1426.

12. Calzuola, I., Marsili, V. and Gianfranceschi, G.L. 2004. Synthesis of antioxidants in wheat sprouts. J Agric Food Chem 2004; 52:5201-5206.

13. Tan, K.W. and Kassim, M.J. A correlation study on the phenolic profiles and corrosion inhibition properties of mangrove tannins (Rhizophora apiculata) as affected by extraction solvents. Corrosion Sci 2011; 53:569-574.

14. Kulkarni, S.D., Acharya, R., Nair, A.G.C. and Reddy, A.V.R. 2006. Determination of elemental concentration profiles in tender wheatgrass (Triticum aestivum L.) using in strumental neutron activation analysis. Food Chem 2006; 4:699-707.

15. Thomson, S.P., Liceaga, A.M., Applegate, B.M. and Martyn, R.D. Analysis of seed vigor responses in soybean to invasive silver carp (Hypophthalmichthys molitrix) protein hydrolysate treatments. Amer J Exp Agric 2015; 5(3):178-191.

16. Milazzo, M.C., Zheng, Z., Kellett, G., Haynesworth, K., Shetty, K. 1999. Stimulation of benzyladenine-induced in vitro shoot organogenesis and endogenous proline in melon (Cucumis melo L.) by fish protein hydrolysates in combination with proline analogues. J Agric Food Chem 1999; 47:1771-1775.

17. Ayek, C.A. and McKell, C.M. Early seedling growth of Italian ryegrass and smilo as affected by nutrition. Department of Agronomy,University of California, Riverside, California; 2002: 29-32.

18. Randhir, R. and Shetty, K., 2003. Light-mediated fava bean (Vicia faba) response to phytochemical and protein elicitors and consequences on nutraceutical enhancement and seed vigour. Proc Biochem 2003; 38:945-952.

19. Mohammad, N. Fall regrowth of crested wheatgrass and fourwing salt bush. Ph.D Dissertation, Utah State University Logan; 1981.

20. Almodares, A., Jafarinia, M. and Hadi, M.R. The effects of nitrogen fertilizer on chemical compositions in corn and sweet sorghum. Amer EurvJ Agri Environ Sci 2009; 6:441-446. 
21. Kapkum, N., Phimphilai, S., Srichairatanakool, S. and Varith, J. Reduction in antioxidant properties lost during processing of a powdered beverage from young organic rice plants. Asian J Food Agro 2011; 4(6):388-398.

22. Mohammad, N., Butt, N.M. and Qamar, I.A. 1988. Effect of nitrogen fertilization and harvesting intervals on the yield and nutritional value of napier grass. Pakistan J Agric Res 1988; 9:478-482.

23. Hasan, M. R., Akbar, M. A., Khandaker, Z. H. and Rahman, M. M. Effect of nitrogen fertilizer on yield contributing character, biomass yield and nutritive value of cowpea forage. Bang J Anim Sci 2010; 39:83-88.

24. Salisbury, F.B. Plant physiology. Wadsworth Publishing Company, Inc., Belmont. Colifornia. 1978.

25. Reinbothe, S., Reinbothe, C. Review: The regulation of enzymes involved in chlorophyll biosynthesis. Eur J Biochem 1996; 237:323-343.

26. Daughtry, C.S.T., Walthall, C.I., Kim, M.S., Brown, D.C.E. and Mcmurtrey, J.E. Estimating corn leaf chlorophyll concentracion from leaf and canopy reflectance. Rem Sens Envi 2000; 74:229-239.

27. Imai, K., Suzuki, Y.J., Mae, T.I. and Makono, A. Changes in the synthesis of Rubisco in rice leaves in relation to senescence and N influx. Ann Bot 2008; 101:135-144.

28. Kansal, B.D., Songh, B., Bajaj, K.L. and Kaur, G. Effect of different levels of nitrogen and farmyard manure on yield and quality of spinach (Spinace oleracea L.). Plant Food Hum Nutr 2005; 31:163-170.

29. Chenard, C.H., Kopsell, D.A.; Kopsell, D. E. Nitrogen concentration affects nutrient and carotenoid accumulation in parsley. J Plant Nutr 2005; 28:285-297.

30. Khumkha O: Factors affecting nutritional value of germinated and seedling cereals. Msc. Dissertation. King Mongkut's University of Technology Thonburi; 2009.

31. Lohr, M., Im, C.S. and Grossman, A.R. 2005. Genome-based examination of chlorophyll and carotenoid biosynthesis in Chlamydomonas reinhardtii. Plant Physiol 2005; 138:490-515.

32. Gibson, S.I. Control of plant development and gene expression by sugar signaling. Cur Opin Plant Biol 2005; 8:93-102.

33. Reif, C., Arrigoni, E., Schaarer, H., Nystroom, L. and Hurrell, R.F. Carotenoid database of commonly eaten Swiss vegetables and their estimated contribution to carotenoid intake. J Food Compos Anal 2013; 29:64-72.

34. Frank, H.A. and Cogdell, R.J. Carotenoids in photosynthesis. Photochem Photobiol 1996; 63:257-264.

35. Moongngarm, A. and Khomphiphatkul, E. Germination time dependence of bioactive compounds and antioxidant activity in germinated rough rice (Oryza sativa L.).Amer J Appl Sci 2011; 8(1):15-25.

36. Eastwood, D., and Laidman, D.L. The mobilization of macronutrient elements in the germinating wheat grain. Phytochem Photobiol 1971; 10:1275-1284.

37. Kaya, M., Küçükyumuk, Z. and Erdal. I. 2009. Phytase activity, phytic acid, zinc, phosphorus and protein contents in different chickpea genotypes inrelation to nitrogen and zinc fertilization. Afr J Biotechnol 2009; 8:4508-4513. 
38. Shetty, K. Biotechnology to harness the benefits of dietary phenolics; focus on Lamiacae. Asia Pac J Clin Nutr 1997; 6(3):162-171.

39. Kraus, T.E.C., Zasoski, R.J. and Dahlgren, R.A. Fertility and pH effects on polyphenol and condensed tannin contents in foliage and roots. Plant Soil 2004; 262(1-2):95-109.

40. Bryant, J.P., Chapin, F.S. and Klein, D.R. Carbon/nutrient balance of boreal plants in relation to vertebrate herbivory. Oikos 1983; 40:357-368.

41. Stefanelli, D., Winkler, S. and Jones, R. Reduced nitrogen availability during growth improves quality in red oak lettuce leaves by minimizing nitrate content, and increasing antioxidant capacity and leaf mineral content. Agric Sci 2011; 2(4):477-486.

42. Nguyen, P.M. and Niemeyer, E.D. Effect of nitrogen fertilization on the phenolic composition and antioxidant properties of basil (Ocimum basilicum L.). J Agric Food Chem 2008; 56:8685-8691.

43. Prior, R.L., Xianli, W. and Schaich, K. Standardized methods for the determination of antioxidant capacity and phenolics in foods and dietary supplements. J Agric Food Chem 2005; 53:4290-4302.

44. Wong, K.P. and Geklim, B. L-DOPA in the seedlings of Vicia faba: its identification, quantification and metabolism. Biogen Amines 1992; 8:73-167.

45. Cano, A., Hernandez-Ruiz, J., Garcia-Canovas, F. and Acosta, M. An end-point method for estimation of the total antioxidant activity in plant material. Phytochem Anal 1998; 9:196-202.

46. Thongboon J, Phimphiliai, S and Srichairatanakool S: Effect of processing on organic rice grass, wheatgrass and barley grass beverages. In Proceedings of the $14^{\text {th }}$ food innovation Asia conference: 14-15 June 2012; Bangkok. Thailand. Edited by Chaiseree S; 2012:36-43. 